\title{
ANALYSIS OF THE DELAMINATION IN DRILLING OF PARTICLEBOARD
}

\begin{abstract}
Particleboard is a wood based composite extensively used in wood working. Drilling is the most commonly used machining process in furniture industries. The surface characteristics and the damage free drilling are significantly influenced by the machining parameters. The thrust force developed during drilling plays a major role in gaining the surface quality and minimizing the delamination tendency. In this study eighteen durability tests of tools for different values of the analyzed cutting parameters were carried out. Based on the obtained results, the effect of cutting parameters of selected signals of axial force and cutting torque was found. Mathematical models using ANOVA, allowing to estimate the value of cutting forces was proposed.
\end{abstract}

Keywords: drilling, feed force, cutting torque, tool wear, laminated chipboard

\section{Introduction}

Particleboard is mainly used for furniture, in flooring, and as panels. Particleboard is a result of the need to utilize large quantities of sawdust at sawmills. Particleboard is usually produced from softwoods and used in panel form. Wood particles are bonded using synthetic adhesives and pressed into sheets. Typically, particleboard consists of a lower density core of coarse particles and outer, higher density layers of finer particles. The board performance is greatly influenced by the distribution of density and particle size [1]. Many applications involve bending loads, where a high-density skin and a low-density core are advantageous. The particleboard panel functions as a sandwich structure and the ratio of bending stiffness to weight becomes high. Machining of wood-based materials causes cutting tools to wear out much faster than machining of solid woods. The use of tungsten carbide tool is also limited because of the relatively high rate of wear [2]. The tungsten carbides were liable to wearing during cutting particleboard and fibreboard due to high temperature oxidation and abrasion $[3,4]$. The machining of particle boards is known to be very difficult because of

\footnotetext{
${ }^{1}$ Autor do korespondencji/corresponding author: Krzysztof Szwajka, Rzeszow University of Technology, Faculty of Mechanical Engineering and Aeronautics, 4 Kwiatkowskiego St., 37-450 Stalowa Wola, Poland, tel. (15) 8448912, e-mail: kszwajka@prz.edu.pl
} 
extremely short tool life [5-8]. The influence of content of mineral contamination has been discussed as the major factor involved in the wearing process of cutting edges during the machining of particle boards $[5,6,9]$ and hightemperature corrosion (HTC) was pointed out as a second important factor impacting tool wear during cutting of particle boards [10]. The density affects most of the physical and mechanical properties of wood composite panels [11-13]. Panel density has been shown to have a considerable impact on flexural properties of wood-based composites [14].

\section{Material and methods}

The experiments were performed on pre-laminated particleboard (PB) $8 \%$ moisture containing and density of $670 \mathrm{~kg} / \mathrm{m}^{3}$, with the thickness of $12 \mathrm{~mm}$ using Faba HW drills with diameter of $10 \mathrm{~mm}$ on Buselatto JET $130 \mathrm{CNC}$ vertical machining centre with a maximum spindle speed of $18000 \mathrm{rpm}$. Experimental set up and drills used for the experiments are shown in fig. 1. The properties of tested PB composites are as follow: $R_{m}=0.43 \mathrm{MPa}, E=2.45 \mathrm{GPa}$. Processing parameters of the tests were: feed $-0.2 ; 0.25$ and $0.3 \mathrm{~mm} / \mathrm{rev}$; cutting speed $-125-377 \mathrm{~m} / \mathrm{min}$ and speed $-4000-12000 \mathrm{~min}^{-1}$. Tests were performed until the maximum value of indicator of tool wear was found. Durability experiments are consisted of repetitive operations, in which each performed 252 holes. Eighteen tests of the tool life were carried out.

a)

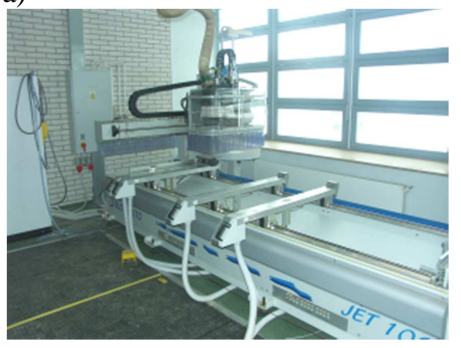

b)

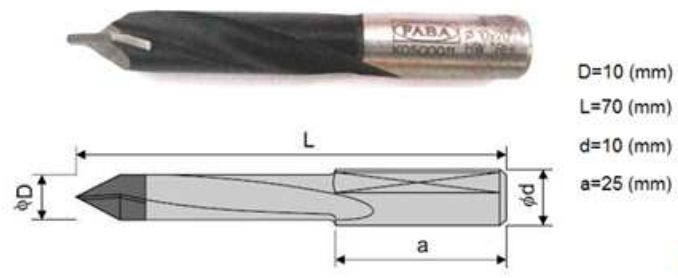

Fig. 1. Experimental setup (a) and drill bits (b) used in the experiments

\section{Measurements}

The main element of the measurement channel was 9345B2-type piezoelectric sensor with preamplifier charge 5073A211 company KISTLER. For the analysis of test results own computer program (LabView programming language) allows to determine the values of recorded signal strength measurements. The program was based on the automatic determination of measurement of recorded signals at specific periods of time signal. As soon as the signal exceeds the axial force $F_{z}$, the threshold is adopted at the level of $150 \mathrm{mV}$ for both signals. 
Determination of these measures lasted until the point at which the signal value of the axial force decreased below $150 \mathrm{mV}$. A simplified diagram of the determination of measurement of signals is shown in fig. 2 .
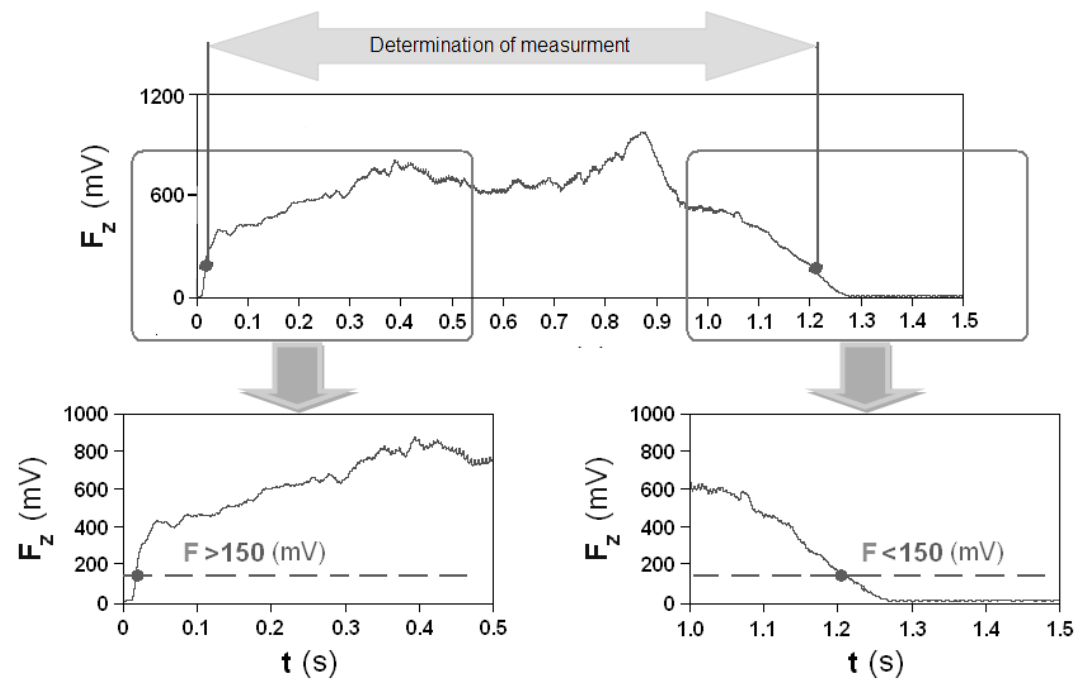

Fig. 2. Method of determining a signal strength measurement $F_{z}$

In these studies as a tool wear indicator $V B_{\max }=0.2 \mathrm{~mm}$ was adopted. The measurement of tool wear was made on the Mitutoyo TM microscope with dropped digital camera eyepiece with a resolution of $600 \mathrm{dpi}$, which allows for image archiving on a personal computer. Tests were carried out till the maximum value of blade wear is accepted. Durability experiments are consisted of repetitive operations, in which each performed 252 holes. After each completed operation, a measurement of tool wear and registration of signal of axial force $F_{z}$, as well as cutting torque $M_{z}$ was carried out.

\section{The test results}

Figure 3. presents examples of obtained waveforms of axial force and cutting torque for new tools (fig. 3a) and wearing tools (fig. 3b). The results of the study, which analysed the axial force $F_{z}$, and cutting moment $M_{z}$ using three different feed rates $f$, five speeds $v_{c}$ and three values of tool wear $V B_{\max }$ are presented below. In the analysis, the effect of feed rate, tool wear and cutting speed on the values of the axial force and cutting torque was studied. In order to determine the effect of tool wear on the cutting force and torque ranges of cutting tool wear was adopted as the independent variable $F_{i}$. The range of the independent variable $\left(F_{i}\right)$ used in the analysis of results are as follow: $F_{1}=0-0.095 ; F_{2}=0.100-0.150$ and $F_{3}=0.155-0.200$. For the present experi- 
ment, ANOVA analysis was performed in STATISTICA program, which allows to evaluate the significance of the impact of three factors on the course of the controlled experiment.
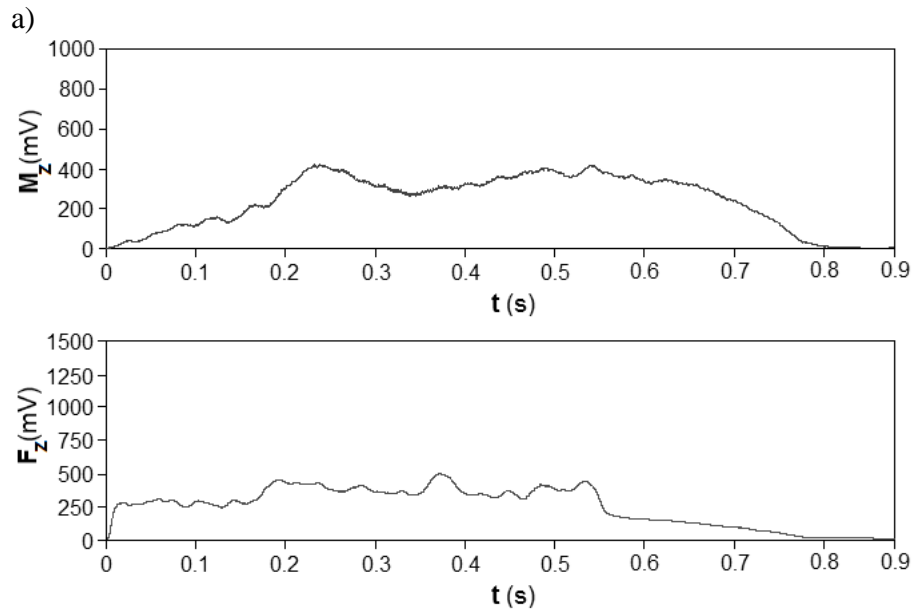

b)
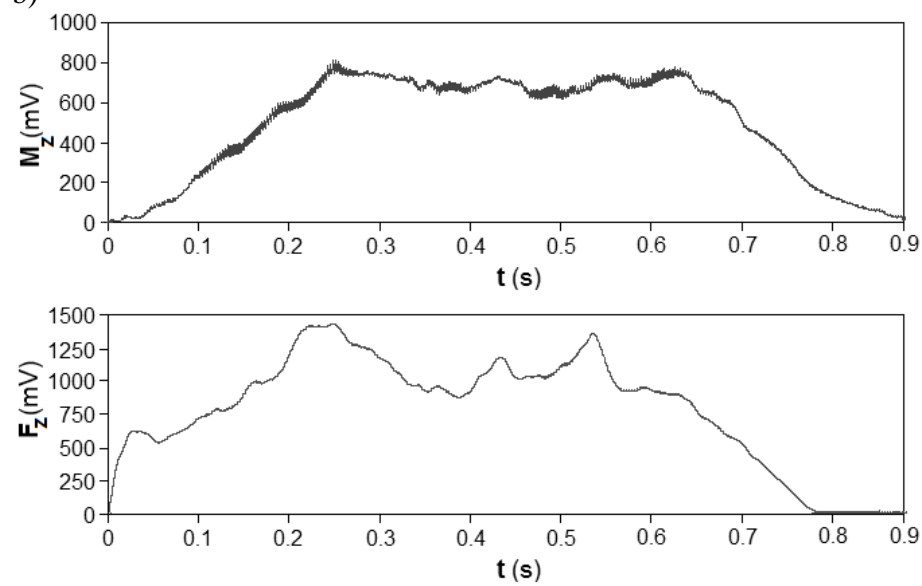

Fig. 3. Exemplary signal waveforms of axial force $F_{z}$ and cutting moment $M_{z}$ for new tools (a) and wearing tools (b)

In this work the level of significance was $p=0.05$. The results of analysis (fig. 4.) rejected hypothesis about the lack of impact of factor and the factor $V B_{\max }$ on the value of the axial force signal $F_{z}$. So it can be noted that the value of tool wear and feed significantly affects the value of the signal strength in drilling. At the significance level $p=0.029$ the effect of cutting speed $v_{c}$ on the value of the axial force signal $F_{z}$ was also noticed. An interaction (statistically significant) between the studied factors was found. The results of analysis (fig. 5.) rejected hypothesis about the lack of impact of factors $V B_{\max }$ and $v_{c}$ (at 
significance level $p=0.020$ ) on the value of the cutting moment $M_{z}$. So it can be noted that the value of tool wear and feed, as well as cutting speed significantly affect the cutting torque during drilling. Furthermore, it is highly significant to consider the interaction of the factors $V B_{\max }$ and $v_{c}$.
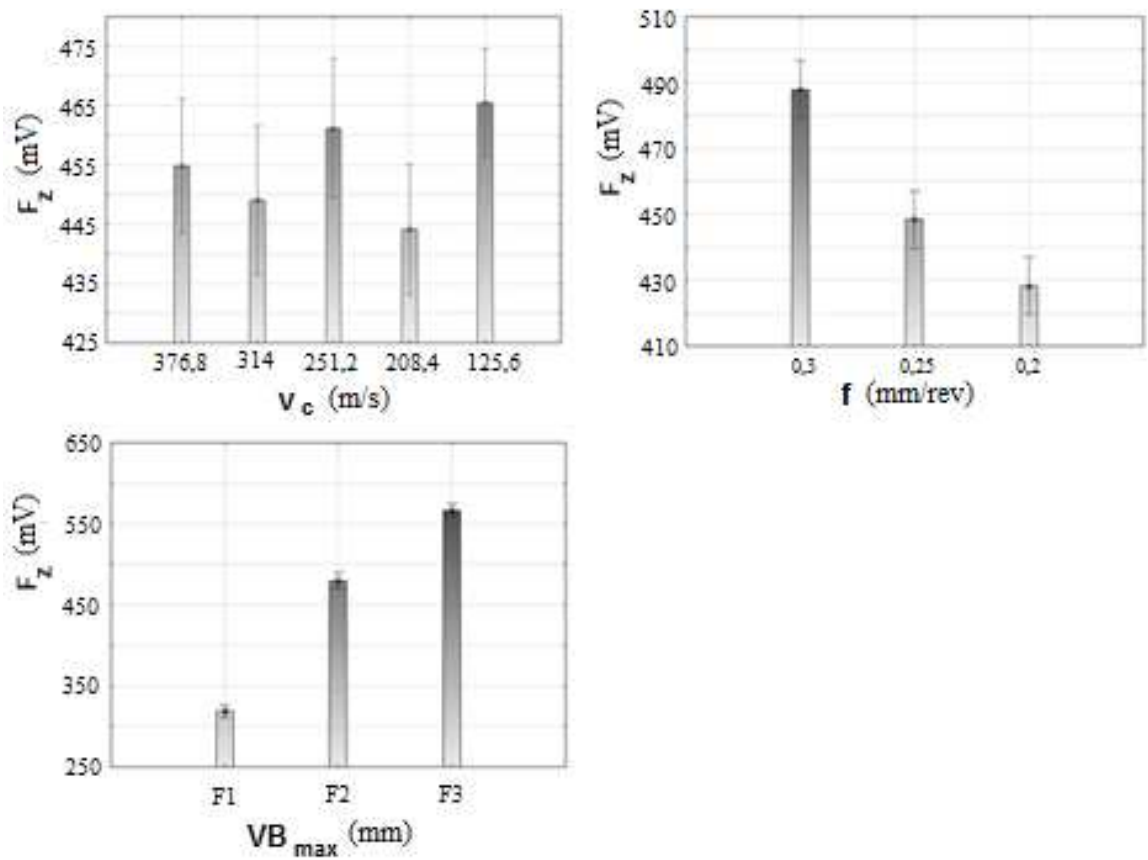

Fig. 4. The influence of cutting parameters on the value of the axial force signal $F_{z}$

Design of cutting tools, especially with complex shapes, such as drills, cutters should be preceded by the optimization process. This requirement is often due to optimization of the fact that the two conflicting criteria must be taken into account at the design stage. This is best illustrated by an ordinary drill, where on one side of the flute cross-section should be as large as possible (this facilitates the discharge of a large quantity of chips) on the other hand, the cross section of the core should be large to increase mechanical strength of the drill, and thus allow the use of higher cutting. Both criteria are mutually contradictory, because of the increase in the diameter of the drill bit flute cross-sectional area helps to reduce the cross-sectional area of the core drill, and vice versa. So finding a compromise solution requires optimization action. The optimization procedure is subject to the earlier diagnosis of the state of charge of such a tool. Distribution of both forces and moments values resulting from the process of the chip affects the wear of cutting edges of the tool. Axial force $F_{z}$ and cutting torque $M_{z}$ are defined as: 


$$
\begin{aligned}
& F_{z}=C_{F} \cdot V B_{\text {max }}^{x_{F}} \cdot f^{y_{F}} \cdot v_{c}^{z_{F}} \\
& M_{z}=C_{M} \cdot V B_{\max }^{x_{M}} \cdot f^{y_{M}} \cdot v_{c}^{z_{M}}
\end{aligned}
$$

where: $C_{F}, C_{M}$ - constants dependent on the processing conditions determined experimentally, $x_{F}, x_{M}$ - exponent characterizing influence of tool wear $V B_{\max }$, $y_{F}, y_{M}$ - exponent characterizing influence of feed $f, z_{F}, z_{M}$ - exponent characterizing influence of cutting speed $v_{c}$.
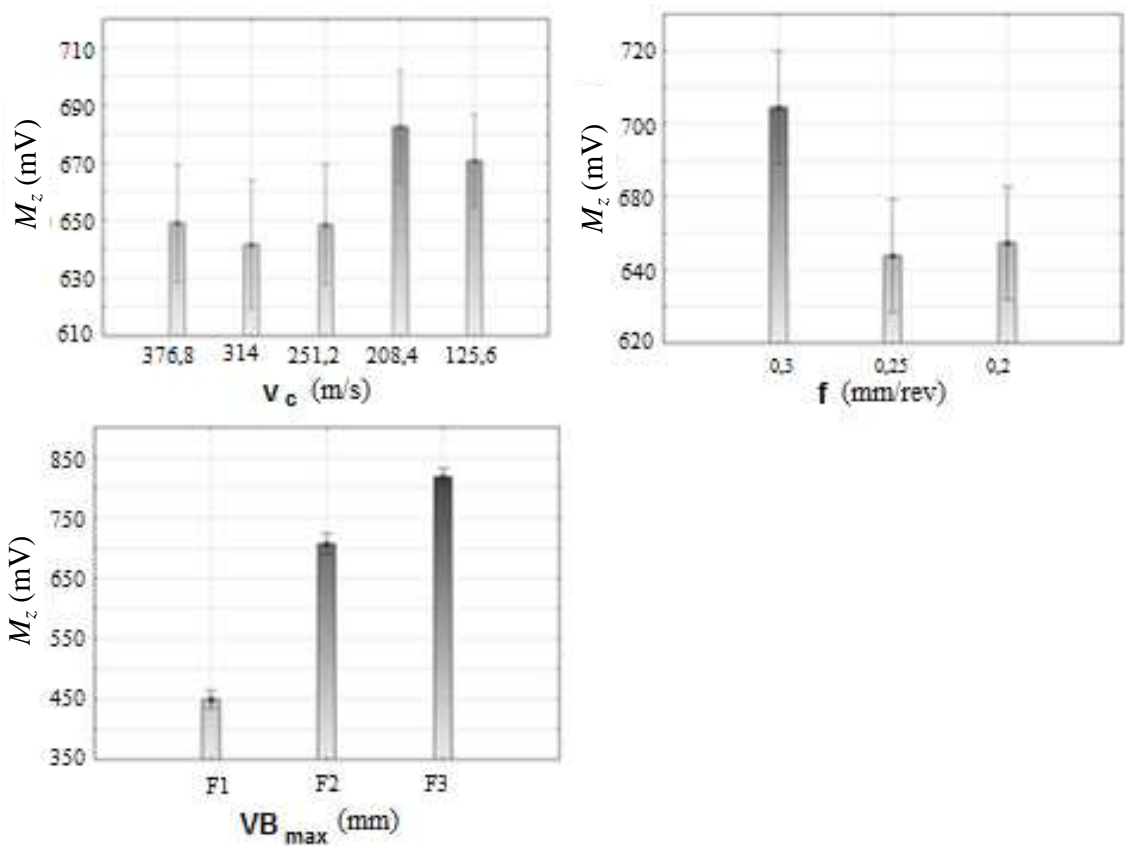

Fig. 5. The influence of cutting parameters on the value of the cutting moment signal $\left(M_{z}\right)$

Below shows the estimate of the signal value of axial force and torque. This resulted in dependence described by eq. (3) and (4):

$$
\begin{aligned}
& F_{z}=1518 V B_{\text {max }}{ }^{0.37} \cdot f^{0.33} \cdot v_{c}{ }^{0.02} \\
& M_{z}=1400 V B_{\text {max }}{ }^{0.47} \cdot f^{0.85} \cdot v_{c}{ }^{1.19}
\end{aligned}
$$

To verify the derived eqs. (3) and (4) a comparative analysis between the actual values, obtained in the study, and the estimated values were carried out, on the basis of these relationships (fig. 6.). 

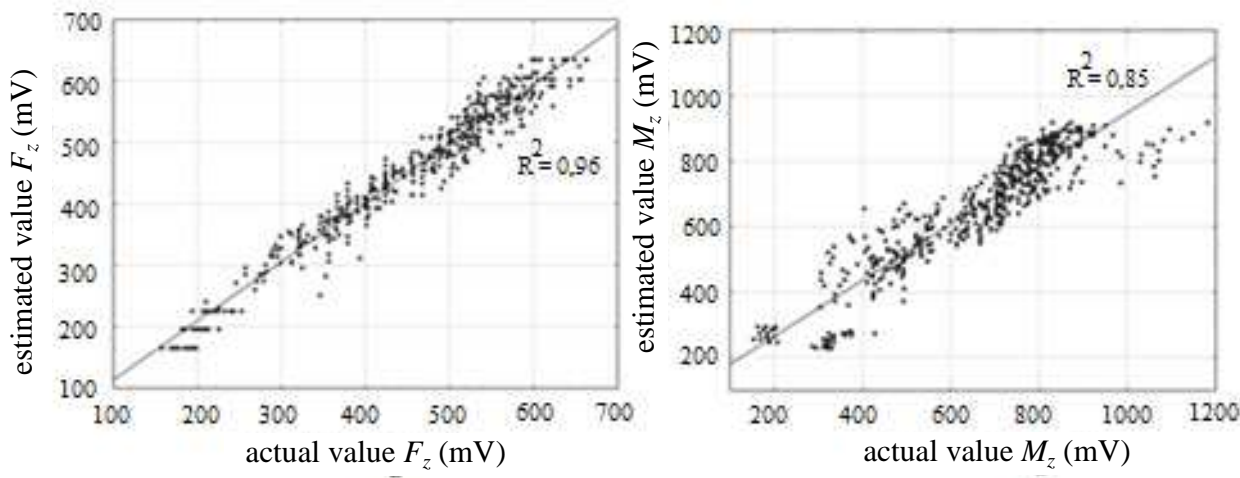

Fig. 6. Actual and estimated values of the axial force $F_{z}$ and the cutting moment $M_{z}$

\section{Conclusions}

Based on the results of analysis and eqs. (3) and (4) it can be seen that the signal of the axial force $F_{z}$ strongly depends on both the tool wear and feed rate. The influence of the cutting speed can be omitted here due to the fact that the value of exponent of $v_{c}$ (eq. (3)) is close to zero. A significant effect of all three independent variables (eq. (4)) on the value of the cutting torque signal $M_{z}$ can be observed.

\section{References}

[1] Berglund L., Rowell R. M.: Wood composites. [In:] R.M. Rowell (ed.): Handbook of wood chemistry and wood composites, CRC Press, Boca Raton 2005.

[2] Darmawan W., Usuki H., Quesada J., Marchal R.: Clearance wear and normal force of TiN-coated P30 in cutting hardboards and wood-chip cement boards. Holz Roh Werkst, 66 (2008), 89-97.

[3] Stewart H.A.: High-temperature halogenation of tungsten carbide cobalt tool material when machining medium density fiberboard. Forest Prod. J., 42 (10) (1992), 27-31.

[4] Sheikh-Ahmad J.Y., Bailey J.A.: High-temperature wear of cemented tungsten carbide tools while machining particleboard and fiberboard, J. Wood Sci., 45 (6) (1999), 445-455.

[5] Bridges R.: A quantitative study of some factors affecting the abrasiveness of particle board. Forest Prod. J., 11 (1971), 39-41.

[6] Porankiewicz B.: Variation in composition of micro-grain cemented carbide and its impact on cutting edge wear during particleboard machining. [In:] Proc. 13th IWMS, Vancouver, Canada, 1997, 791-799.

[7] Porankiewicz B., Gronlund A.: Tool wear-influencing factors. [In:] Proc. 10th IWMS, UC, Berkeley, USA, 1991, 220-229.

[8] Porankiewicz B.: A method to evaluate the chemical properties of particleboard to anticipate and minimize cutting tool wear. Wood Sci. Technol., 37 (1) (2003), 47-58. 
[9] Sparks A.J., Taylor V.: Chip board machinability. Part 1: The effect of cut on cutter wear. Furniture Industry Research Association, 928/271/81 (1981).

[10] Porankiewicz B.: Investigation of chemical wear of cemented carbide cutting edges by processing board materials. Project Report no. MR/USDA-95-219, 1998, 32.

[11] Maloney T.M.: Modern particleboard and dry-process fiberboard manufacturing. Miller Freeman, San Francisco 1993.

[12] Suchsland O., Woodson G.E.: Fiberboard manufacturing practices in the United States. Agriculture Handbook, no. 640, United States Department of Agriculture, 1986.

[13] Kelly M.W.: Critical literature review of relationships between processing parameters and physical properties of particleboard. Gen. Tech. Rep. FPL-10, Forest Products Laboratory, Forest Service, US, Department of Agriculture, USA, 1977, 66.

[14] Chen S., Liu X., Fang L., Wellwood R.: Digital X-ray analysis of density distribution characteristics of wood-based panels. Wood Sci. Technol., 44 (2010), 85-93.

\section{ANALIZA ROZWARSTWIANIA PEYTY WIÓROWEJ PODCZAS WIERCENIA}

\section{Streszczenie}

Płyta wiórowa jest kompozytem, którego podstawowym składnikiem jest drewno. Ma szerokie zastosowanie w przemyśle. Proces wiercenia to najpopularniejszy proces obróbki stosowany w przemyśle meblarskim. Siła osiowa i moment skrawania występujące podczas procesu wiercenia odgrywają ważną rolę w uzyskaniu odpowiedniej jakości powierzchni. W przeprowadzonych badaniach wykonano osiemnaście prób trwałościowych narzędzia dla różnych wartości analizowanych parametrów skrawania. Na podstawie wyników uzyskanych z przeprowadzonych badań określono wpływ wybranych parametrów skrawania oraz zużycia narzędzia na wartość siły osiowej i momentu skrawania. Zaproponowano modele matematyczne, wykorzystując analizę wariancji ANOVA, pozwalające oszacować opory skrawania.

Słowa kluczowe: wiercenie, zużycie narzędzia, jakość powierzchni, płyta wiórowa laminowana

DOI: $10.7862 / \mathrm{rm} .2014 .64$

Otrzymano/received: $26.09 .2014 r$.

Zaakceptowano/accepted: 15.11.2014 r. 